\title{
THE SCALE OF PSYCHO-IMMUNOLOGICAL STRUCTURE: ASSESSING FACTORIAL INVARIANCE IN POLAND AND SLOVAKIA
}

\author{
Adam BIELA ${ }^{1}$, Marian ŠPAJDEL ${ }^{2}$, Jacek ŚLIWAK ${ }^{1}$, Rafał Piotr BARTCZUK ${ }^{1}$, \\ Michał WIECHETEK ${ }^{1}$, Beata ZARZYCKA ${ }^{1}$ \\ ${ }^{1}$ Institute of Psychology, John Paul II Catholic University of Lublin \\ Lublin, Poland \\ E-mail: zarzycka@kul.lublin.pl \\ ${ }^{2}$ Katedra psychológie, Filozofická fakulta, Trnavská univerzita \\ Hornopotočná 23, 91843 Trnava
}

\begin{abstract}
The paper starts with an attempt to develop a hypothetical cognitive structure of mental resiliency, called psycho-immunological system, which plays both a reactive (coping with difficult health situations) and proactive (health protection) role in relation to the human somato-immunological system. In order to answer the question: is the psycho-immunological system invariant in two neighboring cultures, Slovakia and Poland, the authors propose the psychometric operationalization of theoretical constructs of the psycho-immunological system in the form of The Scale of Psycho-immunological Structure (SPS) in both countries. Confirmatory factor analysis revealed that four factors of the scale are equivalent in both samples on the structural level.
\end{abstract}

Key words: mental resilience, psycho-immunological system, measurement of psycho-immunological structure, psychosomatic system

\section{Introduction}

In the light of actual knowledge of the human biological immune system, particularly the discoveries of the 2011 Nobel Prize winners in medicine (Bruce A. Beutler, Jules A. Hoffman, and Ralph M. Steinman), it is clear that there are two steps of human body defense against pathogens. In the first step (socalled nonspecific immunity) the immune system works quickly to prevent infection by receptors called Toll-Like Receptors (TLR), which trigger inflammation and destroy harmful factors in human body. The second line of defense, adaptive immunity, uses the work of dendritic cells, the task of which is to intercept foreign antigens and present them to the immune system. They trigger the reaction of immune system cells lymphocytes - which recognize and eliminate foreign antigens in the body.

Simultaneously with the biological immune system there exists the psychological immune system, which can be referred to as human psycho-immunity. This system performs two main functions. First, it autonomously regulates mechanisms maintaining human psychological health. Second, it contributes to the work of somato-immunological mechanisms by informing them about the physical state of the body.

The concept of mental resilience should be introduced here. It enables a new perspec-

DOI: $10.21909 /$ sp.2015.03.691 
tive in understanding the way in which people maintain their health and well-being when they are faced with difficulties (Charney, 2004; Zautra, Hall, \& Murray, 2010). Mental resilience is understood as a dynamic process that leads to a successful adaptation in the face of encountered difficulties. This type of resilience can be seen as a process, a result of this process or an individual's characteristics (see Luthar, Cicchetti, \& Becker, 2000; Zautra, Arewasikporn, \& Davis, 2010; Allen et al., 2011). According to Masten and O'Dougherty-Wright (2010) there are four elements of psychological resilience: resilience to current problems; the ability to recover, that is to return to previous positive states; a state of normalization caused by the improvement of an external situation; and transformation, being the result of a boost in adaptive consequences. Zautra, Hall and Murray (2010) distinguish two core functions of mental resilience: recovery and sustainability. The first may be operationalized as the time needed to psychologically recover after a functional disorder, while the second one as the range of problems, which a person can cope with without losing his/ her ability to maintain well-being and pursue his/her own important life goals. Mental resilience refers to challenges, life problems, serious stressors and everyday threats (Allen et al., 2011), but also to processes or mechanisms of positive adaptation and growth in terms of significant threats to an individual's life or functions (Zautra, Arewasikporn, \& Davis, 2010). Many psychological structures, playing regulatory functions in maintaining mental health, have been identified in the research. Among them are such rudimentary constructs as free will, value system, sense of coherence, life perspective and life goals.
An important protective measure, helping to boost resilience, constitutes a support system and close interpersonal relationships (Cacioppo, Reis, \& Zautra, 2011). Of importance are also intelligence and the ability to tackle difficulties. Other crucial factors include the role of emotions, self-efficacy, meaningfulness, culture and religion (Janoff-Bulman, 1992; Pargament, Koenig, Tarakeshwar, \& Hahn, 2004; Charuvastra \& Cloitre, 2008; Masten \& O'DoughertyWright, 2010; Furlong et al., 2010; Allen et al., 2011; Śliwak \& Zarzycka, 2012a, 2012b; Głaz, 2013). Zautra, Hall and Murray (2010) distinguished between indicators of resilience effects and resilience resources. The first ones include: an increase in positive emotions and hope, a higher level of variety of emotion complexity, purposefulness and esteem, which are maintained despite stress. The second ones include: sense of coherence, consciousness and clarity in experiencing emotions, sense of belonging, positive emotions, optimism and self-efficacy.

The psychological immune system also contributes to the function of somatic-immune mechanisms by providing information about the physical state and by triggering so-called signal-causing reactions. Those are defense responses to signals regarding health threats which are caused by internal stimuli (through visceroreceptors or proprioreceptor) or external environment. Providing information about physical state refers not only to general health condition but also to the physical state of particular organs and systems.

The fact that psychological functioning is connected with biological processes has been known for 2000 years (Sternberg, 1997). Scientific studies have supported the state- 
ment that psychological mechanisms affect health both directly and indirectly by developing pro-health behavior and through the regulation of neural, immune and endocrine system. For instance, emotions deregulate the production of interleukin 6 (IL 6, a proinflammatory cytokine) and depression, anxiety or hostility increase cytokine production (Kiecolt-Glaser, McGuire, Robles, \& Glaser, 2002).

In our previous works we conducted a synthetic review of psychological constructs connected with human somatic health, and particularly, with the immune system (Biela et al., 2013; Špajdel et al., in print). Our findings showed that psycho-immunological structure consists of four factors: 1) strength and will of meaningful life, 2) sense of competence in coping, 3) social support and proactivity, 4) autonomous goals. They are defined as follows:

The strength and will of meaningful life is an intuitive person's ability to sustain his or her life and to shape the sense of meaning in life. It also includes a conviction that existence in itself is a valuable gift which should be developed and protected (Głaz, 2013; Popielski, 1994; Steger, 2012). The name of the factor was inspired by the Bergson's notion of élan vital. The strength and will of meaningful life enables coping with difficult situations and environmental threat to one's life or health. It also enables people to solve their problems, eliminate stressful situations and makes them more resilient against threats (Steger, Fitch-Martin, Donnelly, \& Rickard, 2014).

Sense of competence in coping is defined as people's beliefs about their capabilities to manage challenges and/or difficult and threatening situations (Schwarzer \& Renner, 2000; Schwarzer \& Fuchs, 1996). Self-efficacy in coping is connected to immunological responses (Wiedenfeld et al., 1990).

Social support and proactivity is defined as the perception that a person is a part of a supportive social network and has the ability to participate in it effectively, in accordance with his or her needs, desires and expectations (Sęk \& Cieślak, 2005; Kirenko \& Byra, 2008). Experience of social support and proactivity is associated with satisfaction from social relations, and with mental and physical health (Thoits, 2011). Autonomous goals are goals that reflect personal interests and values which direct the life activity of a person. Autonomous motivation contains both internal motivation and those types of external motivation which people identify with and integrate into their sense of self. Involvement in pursuing the autonomous goals is associated with mental and physical health indicators (Deci \& Ryan, 2008).

The cultural context of perceiving and individual differences in psychological resilience as well cultural sensitivity of the measurement methods are often neglected in the theory and research (Clauss-Ehlers, 2008; Fletcher \& Sarkar, 2013). Some investigations showed that cultural factors constitute a context for understanding resilience, behaviors in which it is revealed, and ways it's components are related to the health in various societies (Bonnano, 2005; Ungar, 2011; Ungar \& Liebenberg, 2011; Ungar, Ghazinour, \& Richter, 2013; Cheng, Cheung, Chio, \& Chan, 2013). In accordance with the findings mentioned above, the main goal of the present article is the comparative analysis of the results concerning the cognitive structure of psycho-immunological system in Polish and Slovak samples. We do not expect to find many differences in the cognitive structures, because of the cultural closeness of 
the two societies. The outcomes of this analysis will give us a base to construct the equivalent versions of the SPS scales, at least on a factorial structure level.

\section{Method}

The Scale of Psycho-immunological Structure (SPS)

Based on the above-presented structure of mental resiliency, two parallel versions of The Scale of Psycho-immunological Structure (SPS) were developed, in Poland and in Slovakia (Biela et al., 2013; Špajdel et al., in print). The construction of these psychometric tools is the result of cooperation between The Institute of Psychology of the John Paul II Catholic University of Lublin and the Institute of Psychology at Trnava University. The authors of both SPS versions are Adam Biela and Marián Špajdel. The items were generated based on the subject literature, other psychometric tools, and pilot studies. The primary language used during development of the scale was Polish, and then it was translated into Slovak. Translation was carried out via cross-translation procedure, according to the recommendations of the International Test Commission (Humbleton, Merenda, \& Spielberger, 2005). The preliminary elaboration of both versions, by means of the principal component analysis, was also provided (Biela et al., 2013; Špajdel et al., in print).

The SPS version used in the present study contains 29 items rated on a five-point response format from 1 (no/never) to 5 (definitely yes/always). Items form 4 subscales: Strength and Will of Meaningful Life (6 items, e.g., I have a deep sense of meaning in life; I enjoy my life and I experience its joyful- ness almost every day), Sense of Competence in Coping (10 items, e.g. I feel that I'm unable to cope with my duties and concerns (reversed); Recently I have been able to cope with all my troubles without any problems), Social Support and Proactivity (7 items, e.g. In my life there are persons that I think have positive emotions and I am glad to associate with them; There are persons who wish me well but also help in difficult life situations; I have persons in my life that I can rely on for help) and Autonomous Goals (6 items, e.g. I spend each day keeping in mind my goals; I get up willingly every morning to start my daily duties; I set goals which help me behave in an ordered way). Instructions informed the subjects that the questionnaire contains statements about the self, and requested them to read all sentences very carefully and evaluate each of them to the extent it was appropriate for the person. Items were randomly ordered but the order was preserved in Polish and Slovak versions. The questionnaire collected gender and age as personal data.

\section{Subjects}

Polish and Slovak versions of the SPS were the tools for parallel research carried out in Poland and Slovakia. In the Polish study, 375 subjects ( 92 males and 283 females) participated, aged from 18 to 72 years $(M=30$; $S D=11.9)$. The Slovak sample consisted of 266 persons (110 males and 156 females), aged from 18 to $36(M=20.9 ; S D=1.8)$. Initial preparation of data was done by eliminating the outliers cases based on the $\mathrm{D}^{2}$ Mahalanobis distance (subjects were removed when $p<.001$ ): 28 individuals in the Polish (7.5\%) and 16 in the Slovak study group $(6 \%)$. 


\section{Analytical Procedures}

The comparison of Polish and Slovak versions was conducted using Confirmatory Factor Analysis (CFA) with AMOS 21 (Arbuckle, 2006). In order to carry out the testing of the invariance of SPS the following stages were carried out: 1) building of the common model of the hypothetical mental resiliency structure on the basis of the previously obtained results of exploratory factor analyses and testing of the level of invariance of the SPS between two language versions; 2) development of equivalent versions of SPS at least in terms of structural invariance; 3 ) comparative estimation of the reliability of both versions.

\section{Results}

\section{The Level of Invariance Testing}

As a basis for comparison, the common model, containing initially four mutually correlated factors with 29 items, was fit to Polish and Slovak data using multi-group CFA. The measurement invariance was tested by comparison of two models: Unconstrained Model (UM) and Measurement Weights Model (MWM). In UM all parameters were allowed to be different in the Polish and Slovak sample, in MWM it was assumed that all factor loadings are the same in both groups. The models differ significantly $\left(\chi^{2}(29)=89.49\right.$; $p<.001$ ), which means that the method is not invariant on the measurement level. In order to assess to what extent this variability occurs, it was tested which factor loadings are statistically different in both groups. 29 models with the one factor loading set every time as the same in both samples were built and compared to UM. The following items appeared different: i03 $\left(\chi^{2}(1)=8.06 ; p=\right.$ $.005)$; i06 $\left(\chi^{2}(1)=6.78 ; p=.009\right)$; i26 $\left(\chi^{2}(1)=\right.$ $45.74 ; p<.001) ; \mathrm{i} 10\left(\chi^{2}(1)=5.23 ; p=.022\right) ; \mathrm{i} 27$ $\left(\chi^{2}(1)=13.77 ; p<.001\right) ; \mathrm{i} 05\left(\chi^{2}(1)=5.08 ; p=\right.$ $.024)$. Twenty-three out of 29 factor loadings are invariant. The new Measurement Weights Adjusted Model (MWAM), in which factor loadings of the six above mentioned items were set to be different in Polish and Slovak versions but loadings of the all remaining items were constrained equal, was built and compared to $\operatorname{UM}\left(\chi^{2}(1)=8.06\right.$; $p=.005)$. There were no significant differences between MWAM and UM $\left(\chi^{2}(23)=\right.$ 24.43; $p=.381$ ), which means that a common measure of mental resilience structure can be developed on the basis of the MWAM model. In spite of the recognized invariance further steps of common method development will be taken.

\section{Equivalent Versions of SPS Development}

The first step in the SPS development was to test the structural invariance between Polish and Slovak versions. The extension of invariance in intercorrelations between factors was tested by means of comparing two models: MWAM and Structural Covariance Adjusted Model (SCAM), in which the six differences in factor loadings were assumed, but covariances between factors were equally constrained in both samples. These models do not differ $\left(\chi^{2}(23)=24.43 ; p=.381\right)$ as far as inter-relations among the factors constituting the structure of the scale are considered. This means that both versions of SPS are equivalent on the structural level.

In the second step of that stage of analysis, the invariance on the residuals level was tested using comparison of models. SCAM 
Table 1 Goodness of fit statistics for the Final Model

LO HI

\begin{tabular}{cccccccccc}
$\chi^{2}$ & $\mathrm{df}$ & $p$ & CMIN/df & SRMR & RMSEA & RMSEA & RMSEA & TLI & CFI \\
\hline 1223.9 & 604 & $<0.001$ & 2.026 & 0.073 & 0.042 & 0.038 & 0.045 & 0.893 & 0.901 \\
\hline
\end{tabular}

was compared to newly built Measurement Residuals Adjusted Model (MRAM), in which not only covariances between factors were set the same in Polish and Slovak groups but also all items residuals. The outcome was that the compared models differ significantly $\left(\chi^{2}(29)=196.65 ; p<.001\right)$. Thus, although the scale is invariant on the level of structure, it is not on the level of residuals.

Because structural invariance is a sufficient condition for creating equivalent psychometric measures, next steps of scale development were undertaken.

First, the inspection of factor loadings magnitude was carried out. All the loadings in both samples were statistically significant. In reference to six items, differing in Polish and Slovak versions, they only differed in magnitude but were coherent in their signs. They were also statistically significant in both samples. On the basis of the loadings magnitudes, decisions were made as to which items were dropped from the scale. Only three items (i01, i08, and i12) did not reach the assumed level of .4 of loading at least in one version. Therefore, the final number of items in SPS is 26 in both versions compared to the initial number, which was 29.

Second, the inspection of modification indexes was carried out in order to identify items residuals covariances. On this basis covariances between four pairs of items were added $(\mathrm{e} 06 \leftrightarrow \mathrm{e} 07 ; \mathrm{e} 24 \leftrightarrow \mathrm{e} 28 ; \mathrm{e} 26 \leftrightarrow \mathrm{e} 27$ and $\mathrm{e} 10 \leftrightarrow \mathrm{e} 27)$.
Third, the goodness of fit statistics were computed for the obtained Final Model (FM). They are presented in Table 1.

The Chi-Squared test showed poor fit but it is known that this test is too restrictive, and it nearly always rejects the model when large samples are used (Bentler \& Bonnet, 1980; Jöreskog \& Sörbom, 1993). Index of normed $\chi^{2}(\mathrm{CMIN} / \mathrm{df})$ reached an acceptable value in our study (less than 5). Two further fit indexes, RMSEA and SRMR, reached very good values. Incremental fit indices (TLI and CFI) were at about the acceptable level (.90). According to Hu and Bentler's (1999) TwoIndex Presentation Strategy, if RMSEA is 0.06 or lower and a SRMR is 0.09 or lower the fit of the model can be accepted. Our model fulfills this condition.

The final operational model of Polish and Slovak versions of SPS is presented in Figure 1 and the estimates of its parameters are presented in Table 2.

The final operational model consists of four intercorrelated factors. Five items are in factor Will of Meaningful Life. Two of them have different loadings in Polish and Slovak versions and both of them are stronger in the Polish one. The factor Sense of Competence in Coping consists of 9 items. One of them differs between versions in the loading magnitude, which is stronger in the Slovak one. Six items constitute the Social Support and Proactivity factor and loadings of three of them are stronger in the Polish sample. 


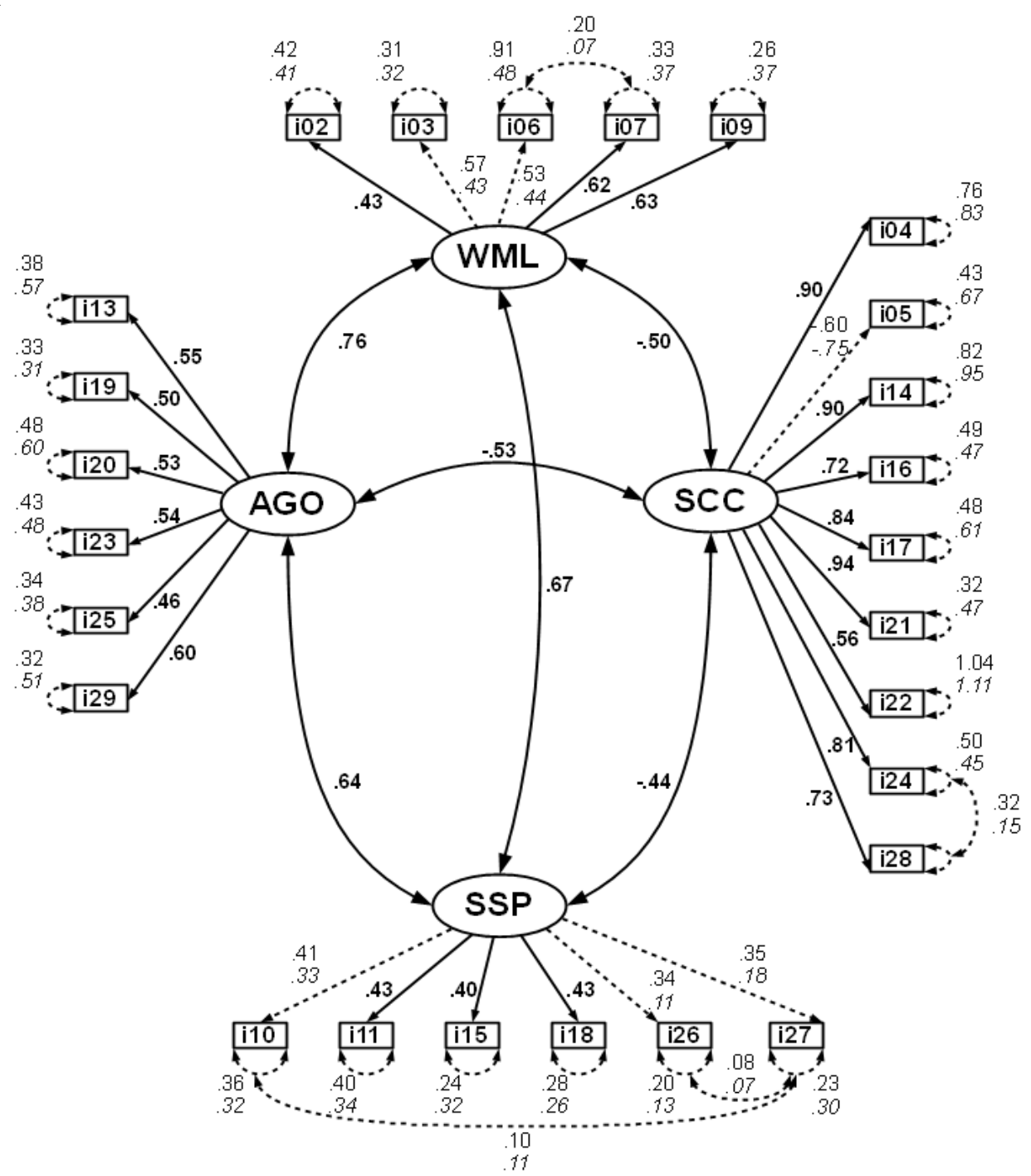

Note. Names of subscales: WML-Strength and Will of Meaningful Life; SCC - Sense of Competence in Coping; SSP - Social Support and Proactivity; AGO - Autonomous Goals

Figure 1 Path diagram of the Final Model 
Table 2 Final operational model of Polish and Slovak versions of SPS - estimates, standardized estimates and factor weights

\section{$\underline{\mathrm{PL}}$}

$\underline{\mathrm{SK}}$

\begin{tabular}{|c|c|c|c|c|c|c|}
\hline Parameter & Estimate & $\begin{array}{c}\text { Standarized } \\
\text { estimate }\end{array}$ & $\begin{array}{c}\text { Factor score } \\
\text { weights }\end{array}$ & Estimate & $\begin{array}{c}\text { Standarized } \\
\text { estimate }\end{array}$ & $\begin{array}{c}\text { Factor score } \\
\text { weights }\end{array}$ \\
\hline \multicolumn{7}{|c|}{$\underline{\text { Regression weights }}$} \\
\hline $\mathrm{i} 02 \leftarrow \mathrm{WML}$ & $0.43 * * *$ & 0.55 & 0.155 & $0.43 * * *$ & 0.56 & 0.189 \\
\hline $\mathrm{i} 03 \leftarrow \mathrm{WML}$ & $0.57 * * *$ & 0.72 & 0.286 & $0.43 * * *$ & 0.61 & 0.244 \\
\hline $\mathrm{i} 06 \leftarrow \mathrm{WML}$ & $0.53^{* * *}$ & 0.49 & 0.032 & $0.44 * * *$ & 0.53 & 0.120 \\
\hline $\mathrm{i} 07 \leftarrow \mathrm{WML}$ & $0.62 * * *$ & 0.73 & 0.268 & $0.62 * * *$ & 0.71 & 0.275 \\
\hline $\mathrm{i} 09 \leftarrow \mathrm{WML}$ & $0.63^{* * *}$ & 0.78 & 0.368 & $0.63 * * *$ & 0.72 & 0.304 \\
\hline $\mathrm{i} 04 \leftarrow \mathrm{SCC}$ & $0.90^{* * *}$ & 0.72 & 0.102 & $0.90 * * *$ & 0.70 & 0.101 \\
\hline $\mathrm{i} 05 \leftarrow \mathrm{SCC}$ & $-0.60 * * *$ & -0.68 & -0.120 & $-0.75 * * *$ & -0.68 & -0.104 \\
\hline $\mathrm{i} 14 \leftarrow \mathrm{SCC}$ & $0.90 * * *$ & 0.71 & 0.094 & $0.90 * * *$ & 0.68 & 0.089 \\
\hline $\mathrm{i} 16 \leftarrow \mathrm{SCC}$ & $0.72 * * *$ & 0.72 & 0.126 & $0.72 * * *$ & 0.73 & 0.142 \\
\hline $\mathrm{i} 17 \leftarrow \mathrm{SCC}$ & $0.84 * * *$ & 0.77 & 0.151 & $0.84 * * *$ & 0.73 & 0.128 \\
\hline $\mathrm{i} 21 \leftarrow \mathrm{SCC}$ & $0.94 * * *$ & 0.86 & 0.248 & $0.94 * * *$ & 0.81 & 0.187 \\
\hline $\mathrm{i} 22 \leftarrow \mathrm{SCC}$ & $0.56^{* * *}$ & 0.48 & 0.021 & $0.56^{* * *}$ & 0.47 & 0.032 \\
\hline $\mathrm{i} 24 \leftarrow \mathrm{SCC}$ & $0.81 * * *$ & 0.76 & 0.140 & $0.81 * * *$ & 0.77 & 0.167 \\
\hline $\mathrm{i} 28 \leftarrow \mathrm{SCC}$ & $0.73 * * *$ & 0.66 & 0.079 & $0.73 * * *$ & 0.70 & 0.115 \\
\hline $\mathrm{i} 10 \leftarrow \mathrm{SSP}$ & $0.41 * * *$ & 0.56 & 0.206 & $0.33 * * *$ & 0.50 & 0.257 \\
\hline $\mathrm{i} 11 \leftarrow \mathrm{SSP}$ & $0.43 * * *$ & 0.56 & 0.227 & $0.43 * * *$ & 0.59 & 0.318 \\
\hline $\mathrm{i} 15 \leftarrow \mathrm{SSP}$ & $0.40 * * *$ & 0.63 & 0.357 & $0.40^{* * *}$ & 0.57 & 0.313 \\
\hline $\mathrm{i} 18 \leftarrow \mathrm{SSP}$ & $0.43 * * *$ & 0.63 & 0.329 & $0.43 * * *$ & 0.65 & 0.421 \\
\hline $\mathrm{i} 26 \leftarrow \mathrm{SSP}$ & $0.34 * * *$ & 0.61 & 0.313 & $0.11^{* * *}$ & 0.31 & 0.228 \\
\hline $\mathrm{i} 27 \leftarrow \mathrm{SSP}$ & $0.35^{* * *}$ & 0.59 & 0.122 & $0.18 * * *$ & 0.31 & 0.002 \\
\hline $\mathrm{i} 13 \leftarrow \mathrm{AGO}$ & $0.55^{* * *}$ & 0.66 & 0.210 & $0.55 * * *$ & 0.58 & 0.163 \\
\hline $\mathrm{i} 19 \leftarrow \mathrm{AGO}$ & $0.50 * * *$ & 0.66 & 0.224 & $0.50 * * *$ & 0.67 & 0.279 \\
\hline $\mathrm{i} 20 \leftarrow \mathrm{AGO}$ & $0.53 * * *$ & 0.61 & 0.165 & $0.53 * * *$ & 0.57 & 0.151 \\
\hline $\mathrm{i} 23 \leftarrow \mathrm{AGO}$ & $0.54 * * *$ & 0.63 & 0.183 & $0.54 * * *$ & 0.61 & 0.191 \\
\hline $\mathrm{i} 25 \leftarrow \mathrm{AGO}$ & $0.46^{* * *}$ & 0.62 & 0.200 & $0.46^{* * *}$ & 0.60 & 0.208 \\
\hline $\mathrm{i} 29 \leftarrow \mathrm{AGO}$ & $0.60 * * *$ & 0.73 & 0.273 & $0.60 * * *$ & 0.64 & 0.200 \\
\hline
\end{tabular}

Table continues 
Table 2 continued

\begin{tabular}{|c|c|c|c|c|c|c|}
\hline \multirow[b]{2}{*}{ Parameter } & \multicolumn{3}{|c|}{$\underline{\mathrm{PL}}$} & \multicolumn{3}{|c|}{$\underline{\text { SK }}$} \\
\hline & Estimate & $\begin{array}{c}\text { Standarized } \\
\text { estimate }\end{array}$ & $\begin{array}{c}\text { Factor score } \\
\text { weights }\end{array}$ & Estimate & $\begin{array}{c}\text { Standarized } \\
\text { estimate }\end{array}$ & $\begin{array}{c}\text { Factor score } \\
\text { weights }\end{array}$ \\
\hline \multicolumn{7}{|c|}{$\underline{\text { Correlations of factors }}$} \\
\hline $\mathrm{WML} \leftrightarrow \mathrm{SCC}$ & & $-0.50 * * *$ & & & $-0.50 * * *$ & \\
\hline $\mathrm{WML} \leftrightarrow \mathrm{SSP}$ & & $0.67 * * *$ & & & $0.67 * * *$ & \\
\hline $\mathrm{WML} \leftrightarrow \mathrm{AGO}$ & & $0.76^{* * *}$ & & & $0.76^{* * *}$ & \\
\hline $\mathrm{SCC} \leftrightarrow \mathrm{SSP}$ & & $-0.44 * * *$ & & & $-0.44 * * *$ & \\
\hline $\mathrm{SCC} \leftrightarrow \mathrm{AGO}$ & & $-0.53 * * *$ & & & $-0.53 * * *$ & \\
\hline $\mathrm{SSP} \leftrightarrow \mathrm{AGO}$ & & $0.64 * * *$ & & & $0.64 * * *$ & \\
\hline \multicolumn{7}{|c|}{$\underline{\text { Correlations of residuals }}$} \\
\hline $\mathrm{e} 24 \leftrightarrow \mathrm{e} 28$ & & $0.38 * * *$ & & & $0.19 * *$ & \\
\hline $\mathrm{e} 10 \leftrightarrow \mathrm{e} 27$ & & $0.36^{* * *}$ & & & $0.34 * * *$ & \\
\hline $\mathrm{e} 06 \leftrightarrow \mathrm{e} 07$ & & $0.36^{* * *}$ & & & $0.18 *$ & \\
\hline $\mathrm{e} 26 \leftrightarrow \mathrm{e} 27$ & & $0.38 * * *$ & & & $0.38 * * *$ & \\
\hline
\end{tabular}

Note. Names of subscales: WML - Strength and Will of Meaningful Life; SCC - Sense of Competence in Coping; SSP - Social Support and Proactivity; AGO - Autonomous Goals ${ }^{*} p<0.05,{ }^{* *} p<0.01,{ }^{* * *} p<0.001$

The loadings of 6 items belonging to the Autonomous Goals factor are the same in both versions. Because some items have different factor loadings for Polish and Slovak versions, in order to obtain factor scores the researcher should use factor weights instead of simple summing or averaging of raw scores. The appropriate factor weights are given in Table 2 as an outcome of the analysis.

Intercorrelations between factors are relatively high. Most strongly related factors are Will of Meaningful Life and Autonomous Goals and the lowest correlation coefficient was obtained between Sense of Competence in Coping and Social Support and Proactivity.
All covariances of residuals considered in the model are intra-factor covariances and are statistically significant in both samples.

\section{Reliability of the Scale}

In order to measure SPS consistency, we computed Cronbach's $\alpha$ coefficient in each sample. Only items which reached the factor loadings values of $>.4$ in the Final Model were included in the subscales. The descriptive statistics of SPS subscales, test of differences between samples and values of the reliability coefficient are presented in Table 3 . 
Table 3 Descriptive statistics of SPS subscales in Polish $(n=343)$ and Slovak $(n=$ 250) samples, test of differences between means in samples and reliability coefficients

\begin{tabular}{ccccccccc} 
Subscale & Sample & Min & Max & $M$ & $S D$ & $t(591)$ & $p$ & $\alpha$ \\
\hline WML $(k=5)$ & PL & 1.20 & 5.00 & 3.70 & 0.66 & -0.95 & 0.34 & 0.81 \\
& SK & 2.20 & 5.00 & 3.75 & 0.56 & & & 0.75 \\
\hline SCC $(k=9)$ & PL & 1.00 & 4.67 & 2.31 & 0.81 & -2.24 & 0.03 & 0.89 \\
& SK & 1.00 & 4.89 & 2.46 & 0.87 & & & 0.90 \\
\hline SSP $(k=3)$ & PL & 2.00 & 5.00 & 4.34 & 0.54 & -0.68 & 0.50 & 0.64 \\
& SK & 2.67 & 5.00 & 4.37 & 0.51 & & & 0.59 \\
\hline AGO $(k=6)$ & PL & 2.17 & 5.00 & 3.79 & 0.59 & 1.79 & 0.07 & 0.82 \\
& SK & 1.83 & 5.00 & 3.70 & 0.61 & & & 0.78
\end{tabular}

Note. $k$ - number of items. Names of subscales: WML - Strength and Will of Meaningful Life; SCC - Sense of Competence in Coping; SSP - Social Support and Proactivity; AGO Autonomous Goals

Sense of Competence in Coping obtained the highest values of reliability coefficient in both samples. When it comes to other scales, the value of the coefficient across the groups ranged from .59 to .78 for the Slovak sample and from .64 to .82 for the Polish one. These values are treated as satisfactory. Lower reliabilities obtained for the Social Support and Proactivity factor probably comes from small number of common items for both versions of the scale. It also should be noted that in the Sense of Competence in Coping factor inter-cultural differences exist (the Polish mean is higher) and the difference in Autonomous Goals approaches significance (the Slovak mean is higher).

\section{Discussion}

The aim of this paper was to compare the cognitive structures of psycho-immunologi- cal system in two cultures: Polish and Slovak. The studies presented in this paper provided evidence for the existence of the four factors of human psycho-immunological structure, which may be treated as common in the Polish and Slovak context. The study allowed to extract the following factors of mental structure: Strength and Will of Meaningful Life; Sense of Competence in Coping; Social Support and Proactivity and Autonomous Goals. The obtained outcomes of the CFA showed that we have reached the confirmation of the existence of a four-factorial structure in both groups. However, the factor loadings of some items differ significantly between the Polish and Slovak group.

Strength and Will of Meaningful Life consists of items, which refer to such theoretical domains as sense of meaning in life, vital force and living will. Such understanding of the content of this factor is in accordance 
with the approach by Bergson (2004), Frankl (1978), Popielski (1994), Reker and Wong (1988). The loadings of two items (I enjoy my life and I experience its joyfulness almost every day; I get up willingly every morning to start my daily duties) which construct this factor are seen to be statistically different. The higher loadings are in the Polish sample, which means that living will, is more strongly connected with the factor expressing Strength and Will of Meaningful Life in Poland than in Slovakia.

Sense of Competence in Coping refers to the ability to struggle with problems of everyday life, health conditions as well as the feeling of being more relaxed. Such interpretation fits the well-known interpretation of coping in literature proposed by Lazarus and Folkman (1984). This dimension is represented by the greatest number of items compared to other dimensions in SPS. It is worth underscoring the fact that in the Slovak sample one of the items (Recently I have been able to cope with all my troubles without any problems) constituting this factor reached a higher loading. This means that this indicator better measures the structure of coping competencies in the Slovak cohort than in the Polish one.

Social Support and Proactivity refer to the friendship of persons who help one in difficult situations, who provide relational and proactive support. This dimension measures mainly the sense of kinds of emotional and instrumental support well-known in the literature (see Schwarzer \& Leppin, 1992). In three items their factorial loadings differed in the compared samples (In my life there are persons that I think have positive emotions and I am glad to associate with them; There are persons who wish me well but also help in difficult life situations; I have per- sons I can rely on for help). The Polish sample is characterized by higher factor loadings. It means that in the Polish group the mentioned items express a closer connection to the core of social support and proactivity.

The last factor, Autonomous Goals, consists of the items describing various connotations and situations of personal aims such as setting and hierarchy of goals. It is the only dimension in the SPS without any differences in factor loadings between the Slovak and Polish sample. We have not neglected the intercultural factors in our research (Clauss-Ehlers, 2008; Fletcher \& Sarkar, 2013). However, as we expected we did not find many differences in the cognitive structures between Polish and Slovak samples, because of cultural closeness of the two societies. The main factorial structure between these societies is invariable (the four factors). The only differences are dealing with items' loadings, which is in line with notions of some researchers, underlying that there are cultural influences in understanding of the resilience content (e.g., Bonnano, 2005; Ungar, 2011). As it was shown in our study, such specific differences can be found even between such close cultures as Polish and Slovak societies.

However, the presented study has some limitations. Taking into account the way of selection of the research sample in Poland and in Slovakia, the generalization of our interpretative conclusions should be reserved only for the intercultural differences among the academic students in both countries. Because of the way the selection of samples was done, some caution is advised in interpreting the findings. The presented SPS test is a psychometric scale to measure the human cognitive psycho-immunological structure. Further development of this scale is re- 
quired in order to improve the items consistency with the factors in all of Slovakia and Poland as well, particularly more efforts should be exerted to increase the reliability of the Social Support and Proactivity factor. It is also necessary to confirm the structure of SPS in a wider population, including special interest groups (e.g., the elderly, retired and people suffering from different diseases) as well as to test the validity of SPS by correlating it with health indicators (especially immunological).

Received May 7, 2014

\section{References}

Allen, R. S., Haley, P. P., Harris, G. M., Fowler, S. N., \& Pruthi, R. (2011). Resilience: Definitions, ambiguities, and applications. In B. Resnick, L. Gwyther, \& K. Roberto (Eds.), Resilience in aging: Concepts, research, and outcomes (pp. 113). New York: Springer Publishers.

Arbuckle, J. L. (2006). Amos (Version 7.0) [Computer Program]. Chicago: SPSS.

Bentler, P. M., \& Bonett, D. G. (1980). Significance tests and goodness of fit in the analysis of covariance structures. Psychological Bulletin, 88 , 588-606.

Bergson, H. (2004). Energia duchowa [Spiritual Energy]. Warszawa: Wydawnictwo IFiS PAN.

Biela, A., Špajdel, M., Śliwak, J., Bartczuk, R. P., Szymołon, J., Wiechetek, M. P., \& Zarzycka, B. (2013). Odporność psychiczna: Jej struktura $i$ konstrukcja Skali Struktury Psychoimmunologicznej (SPS) [Mental resilience: Its structure and the construction of the Scale of Psychoimmunological Structure (SPS)]. Czasopismo Psychologiczne, 19(2), 375-389.

Bonanno, G. A. (2005). Resilience in the face of potential trauma. Current Directions in Psychological Science, 14(3), 135-138. http://doi: 10.1111/j.0963-7214.2005.00347.x

Cacioppo, J. T., Reis, H. T., \& Zautra, A. J. (2011). Social resilience: The value of social fitness with an application to the military. American Psychologist, 66, 43-51.

Charney, D. (2004). Psychobiological mechanisms of resilience and vulnerability: Implications for successful adaptation to extreme stress. American Journal of Psychiatry, 161(2), 195-216.

Charuvastra, A., \& Cloitre, M. (2008). Social bonds and posttraumatic stress disorder. Annual Review of Psychology, 59, 301-328.

Cheng, C., Cheung, S., Chio, J. H., \& Chan, M. S. (2013). Cultural meaning of perceived control: A meta-analysis of locus of control and psychological symptoms across 18 cultural regions. Psychological Bulletin, 139(1), 152-188.

Clauss-Ehlers, C. S. (2008). Sociocultural factors, resilience, and coping: Support for a culturally sensitive measure of resilience. Journal of Applied Developmental Psychology, 29(3), 197212.

Deci, E. L., \& Ryan, R. M. (2008). Self-determination theory: A macrotheory of human motivation, development, and health. Canadian Psychology/Psychologie Canadienne, 49(3), 182185.

Fletcher, D., \& Sarkar, M. (2013). Psychological resilience: A review and critique of definitions, concepts, and theory. European Psychologist, 18(1), 12-23. doi:10.1027/1016-9040/a000124

Frank1, V. E. (1978). Homo patiens. Warszawa: Instytut Wydawniczy PAX.

Furlong, L. V., Zautra, A. J., Puente, C. P., López, P., \& Valero, P. B. (2010). Cognitive-affective assets and vulnerabilities: Two factors influencing adaptation to Fibromyalgia. Psychology and Health, 25, 197-212.

Głaz, S. (2013). The role of the meaning of life and religious experience of God's presence and God's absence among students with different levels of conscience sensitivity. Religions, 4, 132-144.

Humbleton, R. K., Merenda, P. F., \& Spielberger, C. D. (2005). Adapting educational and psychological tests for cross-cultural assessment. Mahwah, New York: L. Erlbaum Associates.

Hu, L. T., \& Bentler, P. M. (1999). Cutoff criteria for fit indexes in covariance structure analysis: Conventional criteria versus new alternatives. Structural Equation Modeling, 6, 1-55.

Janoff-Bulman, R. (1992). Shattered assumptions: Towards a new psychology of trauma. New York: Free Press.

Jöreskog, K. G., \& Sorbom, D. (1993). LISREL 8: Structural equation modeling with the SIMPLIS command language. Chicago: Scientific Software International.

Kiecolt-Glaser, J. K., Mcguire, L., Robles, T. F., \& Glaser, R. (2002). Emotions, morbidity, and mortality: New perspectives from psychoneuro- 
immunology. Annual Review in Psychology, 53, 83-107.

Kirenko, J., \& Byra, S. (2008). Zasoby osobiste w chorobach psychosomatycznych [Personal resources in psychosomatic diseases]. Lublin: Wydawnictwo Uniwersytetu Marii CurieSkłodowskiej.

Lazarus, R. S., \& Folkman, S. (1984). Stress, appraisal and coping. New York: Springer Publishing.

Luthar, S., Cicchetti, D., \& Becker, B. (2000). The construct of resilience: A critical evaluation and guidelines for future work. Child Development, $71(3), 543-562$.

Masten, A. S., Wright, M. O. (2010). Resilience over the lifespan: Developmental perspectives on resistance, recovery and transformation. Handbook of Adult Resilience, 213-237.

Masten, A., \& O’Dougherty-Wright, M. (2010). Resilience over the lifespan: Developmental perspectives on resistance, recovery, and transformation. In J. W. Reich, A. J. Zautra, \& J. Stuart Hall (Eds.), Handbook of adult resilience (pp. 213-237). New York: Guilford

Pargament, K. I., Koenig, H. G., Tarakeshwar, N., Hahn, J. (2004). Religious coping methods as predictors of psychological, physical and spiritual outcomes among medically ill elderly patients: A two-year longitudinal study. Journal of Health Psychology, 9, 713-730.

Popielski, K., (1994). Noetyczny wymiar osobowości [Noetic dimension of personality]. Lublin: RW KUL.

Reker, G. T., \& Wong, P. T. P. (1988). Aging as an individual process: Toward a theory of personal meaning. In J. E. Birren, \& V. L. Bengston (Eds.), Emergent theories of aging (pp. 214-246). New York, NY: Springer.

Schwarzer, R., \& Fuchs, R. (1996). Self-efficacy and health behaviours. In M. Conner, \& P. Norman (Eds.), Predicting health behaviour: Research and practice with social cognition models (pp. 163-196). Buckingham: Open University Press.

Schwarzer, R., \& Leppin, A. (1992). Possible impact of social ties and support on morbidity and mortality. In H. O. F. Veiel, \& U. Baumann (Eds.), The meaning and measurement of social support (pp. 65-83). Washington, DC: Hemisphere.

Schwarzer, R., \& Renner, B. (2000). Social-cognitive predictors of health behavior: Action self efficacy and coping self-efficacy. Health Psychology, 19(5), 487-495.
Sęk, H., \& Cieślak, R. (Eds.). (2012). Wsparcie spoleczne, stres $i$ zdrowie [Social support and health]. Warszawa: Wydawnictwo Naukowe PWN.

Špajdel, M., Biela, A., Śliwak, J., Bartczuk, R. P., Szymołon, J., Wiechetek, M. P., \& Zarzycka, B., (in print). Psychická odolnost': Jej štruktúra a konštrukcia Škály Psychoimmunologickej Štruktúry [Psychological resilience: Its structure and development of the Scale of Psychoimmunological Structure]. Československá Psychologie.

Steger, M. F. (2012). Making meaning in life. Psychological Inquiry, 23, 381-385.

Steger, M. F., Fitch-Martin, A. R., Donnelly, J., \& Rickard, K. M. (2014). Meaning in life and health: Proactive health orientation links meaning in life to health variables among American undergraduates. Journal of Happiness Studies, 1-15.

Sternberg, R. J. (1997). A triarchic view of giftedness: Theory and practice. In N. Coleangelo, \& G. A. Davis (Eds.), Handbook of gifted education (pp. 43-53). Boston, MA: Allyn and Bacon.

Śliwak, J., \& Zarzycka, B. (2012a). The interplay between post-critical beliefs and anxiety: An exploratory study in a Polish sample. Journal of Religion and Health, 51(2), 419-430.

Śliwak, J., \& Zarzycka, B. (2012b). The interplay between post-critical beliefs and self-consciousness. Polish Psychological Bulletin, 43(3), 173182.

Thoits, P. A. (2011). Mechanisms linking social ties and support to physical and mental health. Journal of Health and Social Behavior, 52(2), 145-161.

Ungar, M. (2011). The social ecology of resilience: Addressing contextual and cultural ambiguity of a nascent construct. American Journal of Orthopsychiatry, 81(1), 1-17. doi:10.1111/j.1939$0025.2010 .01067 . x$

Ungar, M., Ghazinour, M., \& Richter, J. (2013). Annual research review: What is resilience within the social ecology of human development? Journal of Child Psychology and Psychiatry, 54(4), 348-366.

Ungar, M., \& Liebenberg, L. (2011). Assessing resilience across cultures using mixed methods: Construction of the child and youth resilience measure. Journal of Mixed Methods Research, 5(2), 126-149.

Wiedenfeld, S. A., O’Leary, A., Bandura, A., Brown, S., Levine, S., \& Raska, K. (1990). Impact of perceived self-efficacy in coping with stressors on components of the immune system. Journal 
of Personality And Social Psychology, 59(5), 1082-1094.

Zautra, A. J., Arewasikporn, A., \& Davis, M. C. (2010). Resilience: Promoting well-being through recovery, sustainability, and growth. Research in Human Development, 7, 221-238.
Zautra, A. J., Hall, J., \& Murray, K. E. (2010). Resilience: A new definition of health for people and communities. In J. W. Reich, A. J. Zautra, \& J. Hall (Eds.), Handbook of adult resilience (pp. 3-29). New York, NY: Guilford Press.

\title{
ŠKÁLA PSYCHOIMUNOLOGICKEJ ŠTRUKTÚRY: ZISŤOVANIE FAKTOROVEJ INVARIANCIE V POLSKU A NA SLOVENSKU
}

A. B i e 1 a, M. Š pajde l, J. Ś 1 i wak, R. P. B a r t c z u k, M. W i e c he te k,

\author{
B. Z a r z y c k a
}

Súhrn: Článok na úvod predstavuje pokus o vytvorenie hypotetickej kognitívnej štruktúry psychickej odolnosti nazývanej psychoimunologický systém, ktorý zohráva reaktívnu (zvládanie t’ažkých zdravotných situácií) aj proaktívnu (ochrana zdravia) úlohu vo vzt'ahu k l’udskému somatoimunologickému systému. Odpoved’ou na otázku "je psychoimunologický systém invariantný v dvoch susediacich kultúrach, pol'skej a slovenskej" môže byt' autormi navrhnutá psychometrická operacionalizácia teoretického konštruktu psychoimunologického systému v podobe Škály psychoimunologickej štruktúry (SPS) v oboch krajinách. Konfirmačná faktorová analýza odhalila, že štyri faktory škály sú na štrukturálnej úrovni rovnaké v oboch výberoch. 